\title{
Influence of Glycemic Index-Based Menu on Endurance Performance of Athletes
}

\author{
Wilda Welis ${ }^{1}$, Rimbawan $^{2}$, Ahmad Sulaeman $^{2}$ \& Hadi Riyadi ${ }^{2}$ \\ ${ }^{1}$ Faculty of Sports Science, Univesitas Negeri Padang, Indonesia \\ ${ }^{2}$ Departement of Gizi Masyarakat, FEMA, Institut Pertanian Bogor, Bogor, Indonesia \\ Correspondence: Wilda Welis, Faculty of Sports Science, Universitas Negeri Padang, Jl. Prof. Dr. Hamka - Air \\ Tawar, Padang, Sumatera Barat, Indonesia. E-mail: wildawelis@yahoo.co.id.
}

\author{
Received: February 12, 2014 Accepted: February 20, 2014 Online Published: February 28, 2014 \\ doi:10.5539/ass.v10n5p173 URL: http://dx.doi.org/10.5539/ass.v10n5p173
}

\begin{abstract}
Carbohydrate plays an important role in physical activity including in sports. However, consuming high carbohydrates before exercises can cause metabolic effects, i.e. unfavorable hyperglycemia and hyperinsulinemia in endurance performance before training. This research is aimed at knowing the influence of meal consumption with different glycemic indexes (GI) on the endurance performance of athletes involving in 5-km run. This research uses controlled random experimental design. The subjects taking part in this research are 15 athletes, consisting of 8 persons in low-GI group and 7 persons in high-GI group. After overnight fasting, the subjects consume the intervening meals in accordance with their groups (low GI or high GI) three hours before 5-km run. The intervening meals contain 1000 calories with glycemic indexes of 37 and 85 . The average age of the subjects is $19.0 \pm 0.8$ years, while the average body weight, body height, and body fat percentage is $56.2 \pm 8.9 \mathrm{~kg}, 163.8$ $\pm 6.8 \mathrm{~cm}$ and $17.78 \pm 4.50 \%$, respectively. The average hemoglobin, hemotocrite, and $\mathrm{VO}_{2 \max }$ of the subjects is $16.24 \pm 1.54 \mathrm{mg} / \mathrm{dl}, 43.61 \pm 2.81 \%$ and $44.99 \pm 6.00 \mathrm{ml} / \mathrm{kg} \mathrm{BB} /$ minutes, respectively. The research findings show that, before and after interventions, the average finish times in 5-km running in the subjects with low-GI group are $23.85 \pm 1.64$ minutes and $23.91 \pm 1.46$ minutes faster than those with high-GI group $(27.51 \pm 2.21$ and $26.95 \pm 3.11$ minutes). This study concludes that there is an influence of meal consumption with different GIs to performance of endurance in $5-\mathrm{km}$ run among college athletes $(\mathrm{p}<0.05)$.
\end{abstract}

Keywords: glycemic index, endurance performance, blood glucose, insulin serum

\section{Introduction}

Carbohydrate is a main energy-providing nutrient in various physical activities including sports because it can be used immediately to function muscle movement, brain, liver, and red blood cells. The use of carbohydrate increases with increasing sport intensity. The decrease of carbohydrate storage closely relates to an emerging muscle fatigue because of the lowering pyruvate level that triggers the occurrence of ATP-producing Krebs cycle (Powers \& Hawley, 1997). The problem faced by an athlete is how to maintain the carbohydrate supply in muscles and to slow down the reduction of muscle glycogen reserve that impairs an emerging fatigue. Thus far, athletes are usually suggested to consume high-carbohydrate meal before participating in a game or training. However, the reality shows that an athlete's endurance to complete the game is yet to be optimal. A rich-carbohydrate meal is suggested for an athlete who does sport activities with physical endurance (Sukmaniah \& Prastowo, 1992). However, the high-carbohydrate consumption before training can raise metabolic effects, i.e. unfavorable hyperglycemia and hyperinsulinemia in performance before training (Jeukendrup \& Gleeson, 2004). The increase of plasma insulin will depress the fat metabolism and increase the carbohydrate oxidation that causes a decrease of plasma glucose concentration for subsequent training. A strategy is needed to minimize the effect of high-carbohydrate consumption in attaining an optimal endurance because heavy sport training can also increase the oxidative stress level. Jenkins et al. (1981) published a concept that is corresponding to the carbohydrate known as glycemic index (GI). According to this concept, the carbohydrates contained in meals that are quickly broken down during digestion have a high glycemic index, and the blood glucose response to the meals is quick and high; reversely, the carbohydrates that are broken down gradually have a low glycemic index, releasing glucose slowly into bloods (Rimbawa \& Siagian, 2004).

An investigation on glycemic index in trained cyclists, conducted by Thomas et al. (1994), found that the 
athletes with low-GI consumption have 20-minute longer endurance than those with high-GI consumption. Similarly, Wu and Williams' investigation (2006) indicates that the time taken for completing training is shorter within those consuming low-GI meals than those with high-GI meal, while the rates of fatty oxidation are higher within those with low-GI meal than with high-GI meal. The finding of investigation from Moore et al. (2009) also shows that there is a significant increase in performance time after consuming low-GI food rather than that of high-GI food. In addition, the blood glucose concentration at fatigue point is significantly higher after consuming low-GI meal than high-GI meal. This investigation also indicates that there is a significant increase in performance time after consuming low-GI meal in relation to the increase of glucose availability in muscle activity and there is an additional contribution to carbohydrate oxidation and a likelihood of preserving the muscle and liver glycogen reserves.

However, an investigation of Mitchell et al. (1997) shows that the consumption of carbohydrate does not influence the endurance during training. Stannard et al. (2000) found no significant difference in low-GI and high-GI consumption effects to time of fatigue. Another research conducted by Chen et al. (2008) shows no significant difference in the time to complete $50-\mathrm{km}$ running between high-GI and low-GI treatments. From these controversies in the investigation findings of GIs related to endurance, a research is necessary to strengthen the existing findings.

The research aims to study the influences of consuming meals with different GIs on the performance endurance of athletes in 5-km run. The specific objectives were:

1) To know the profiles of $\mathrm{VO}_{2 \max }$, hemoglobin, hemotocrite, and body mass index (BMI)

2) To analyze the effects of meals with different GIs on serum insulin and blood glucose levels.

3) To test the influence of consuming meals with different GIs on the performance endurance in 5-km run.

\section{Methodology}

The design of this research is a controlled random experiment that studies the GI effects on the endurance performance of running among college athletes. The subjects of research were male students of $19-25$ years old The students are active in sport trainings. Some inclusion criteria are having followed trainings in various sports routinely for at least 6 months, having agreed to take part in this research until its completion by signing an informed consent, is healthy for the last month, not smoking and not drinking alcohol. The number of subjects taking part in this research is 15 persons, who are randomized into two groups of treatments - high-GI group and low-GI group.

The data taken for this research are the subjects' characteristics. These are age, body weight, body height, BMI, and body-fat percentage; venous blood samples for examining the levels of serum insulin, blood glucose and blood lactates, hemoglobin, hematocrite and finish times in 5-km run. The intervening meals with high GI (GI $=85$ ) and low GI $(\mathrm{GI}=37)$ containing 1000 calories consisting of $70 \%$ carbohydrates, $15 \%$ proteins and $15 \%$ fats for one meal and the meals were provided three times a day during two weeks. The mixed GIs meals are calculated from the table by Foster-Powell et al. (2002) as well as from Warta Penelitian and Pengembangan Pertanian (2009).

At the initial and final interventions, the samplings of bloods and endurance performances in 5-km run are made three hours following consumption of the meals. The examination of blood glucose concentrations is measured by using a glucometer. The levels of serum insulin are determined by the ELISA method using the commercial kit. The levels of hematocrite are examined with spectrophotometer and the levels of hemoglobin with cyanmethemoglobin. The performances of 5-km running are taken on a treadmill.

The research findings are shown in the form of mean and standard deviation $(\mathrm{x} \pm \mathrm{sd})$. The influences of meal consumption with different GIs on endurance performance in $5-\mathrm{km}$ run are tested with $t$-tests. To know the influences of meal consumption with different glycemic indexes on blood glucose and serum insulin levels, the ANOVA test is used. The reliability level used for the whole analysis is $95 \%$.

\section{Results and Discussion}

Body Mass Index (BMI) calculated from body weight and height has played a role in athletes' performances. The results of measurement show that $67 \%$ subjects were in the under-nutrient and fat categories. The average BMI in this research is $20.91 \pm 2.81 \mathrm{~kg} / \mathrm{m}^{2}$ and is in the good/normal categories. From the body fat percentage, the subjects were average with $17.7 \pm 4.50 \%$ in body fats. This indicates that the subject body fat percentage is in the intermediate category. The body fat percentage is in intermediate category when the value is between 15 and 17 percent for men and 20 and 24 percent for women (Depdiknas, 2000). 
The average hemoglobin level within the subjects is $16.24 \pm 1.54 \mathrm{~g} / \mathrm{dl}$ and this value is in the normal category. According to Mougios (2006), the concentrations of normal blood hemoglobin for men of 18 to 44 years old are between 13.2 and $17.3 \mathrm{~g} / \mathrm{dl}$. The uptake of lowest maximal oxygen $\left(\mathrm{VO}_{2 \max }\right)$ in the subjects with low-GI group is $28.8 \mathrm{ml} / \mathrm{kg} \mathrm{BB} /$ minutes and with high-GI group $38.5 \mathrm{ml} / \mathrm{kg} \mathrm{BB} /$ minutes; meanwhile, the highest $\mathrm{VO}_{2 \max }$ in the subjects with low-GI group and high-GI group is $54.38 \mathrm{ml} \mathrm{BB} /$ minutes. The tests of differences indicate that there is no significant difference for the subject characteristics $(\mathrm{p}>0.05)$ in age, body weight, body height, BMI, body fat percentage, hemoglobin, hematocrit and maximal oxygen uptake $\left(\mathrm{VO}_{2 \max }\right)$ for both intervened groups. The mean data of subject characteristics is shown in the Table 1.

Table 1. The characteristics of the subjects

\begin{tabular}{lccc}
\hline Description & High GI $(\mathrm{n}=7)$ & Low GI $(\mathrm{n}=8)$ & Average $(\mathrm{n}=15)$ \\
\hline Age (years) & $19.14 \pm 0.69$ & $18.88 \pm 0.83$ & $19.00 \pm 0.76$ \\
Body weight $(\mathrm{kg})$ & $58.64 \pm 12.16$ & $54.00 \pm 4.69$ & $56.17 \pm 8.95$ \\
Body height $(\mathrm{cm})$ & $161.94 \pm 6.49$ & $165.35 \pm 7.13$ & $163.76 \pm 6.82$ \\
$\mathrm{VO}_{2 \max }(\mathrm{ml} / \mathrm{kg} \mathrm{BB} / \mathrm{min})$. & $43.78 \pm 6.13$ & $46.04 \pm 6.09$ & $44.99 \pm 6.00$ \\
Body fat percentage & $19.16 \pm 5.59$ & $16.57 \pm 3.18$ & $17.78 \pm 4.50$ \\
Hemoglobin (\%) & $16.55 \pm 1.33$ & $15.96 \pm 1.75$ & $16.24 \pm 1.54$ \\
Hemotocrite (\%) & $43.78 \pm 1.66$ & $43.43 \pm 3.78$ & $43.61 \pm 2.81$ \\
BMI $\left(\mathrm{kg} / \mathrm{m}^{2}\right)$ & $21.19 \pm 2.35$ & $19.76 \pm 1.47$ & $20.91 \pm 2.81$ \\
\hline
\end{tabular}

In the first day of intervention, the average level of postprandial blood glucose within low-GI group subjects is $98.75 \pm 12.08 \mathrm{mg} / \mathrm{dl}$. The average value of postprandial glucose is lower within low-GI group subjects than high-GI group subjects with the average value of $106.29 \pm 17.31 \mathrm{mg} / \mathrm{dl}$. However, the average blood glucose after $5-\mathrm{km}$ run in the subjects with low-GI group is in fact higher $(110.63 \pm 15.97 \mathrm{mg} / \mathrm{dl})$ than in those with high-GI group $(102.29 \pm 16.23 \mathrm{mg} / \mathrm{dl})$. From the average glucose level two hours after meal consumption (postprandial/PP) with glucose level when fasting, the increase of glucose level in high-GI group is larger than low-GI group. However, from the difference between postprandial (PP) glucose level and running in high-GI group, there is a reduction of blood glucose level after 5-km run. However, statistically there is no average difference of postprandial blood glucose levels within both intervention groups $(\mathrm{p}>0.05)$. The average blood glucose in the two subject groups can be viewed in Figure 1.

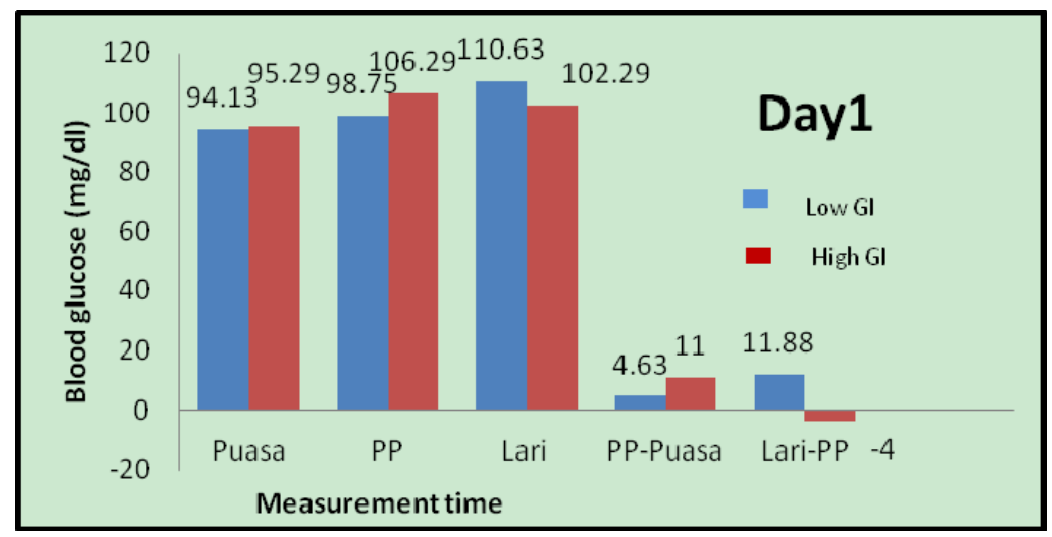

Figure 1. The average blood glucose levels in subjects on day 1

On the $15^{\text {th }}$ day of intervention, the average postprandial blood glucose level is actually higher in the subjects with low-GI group than those with high-GI group. From the difference between PP blood glucose level and glucose level when fasting, the high-GI group is relatively higher than the low-GI group. Similarly, the average difference between glucose level after 5-km run and fasting is shown to be higher in high-GI group than low-GI group. The results of statistical tests suggest that there is no difference of average blood glucose level between the two treatments $(p>0.05)$. The average blood glucose level in both treatment groups on day 15 can be viewed 
in Figure 2.

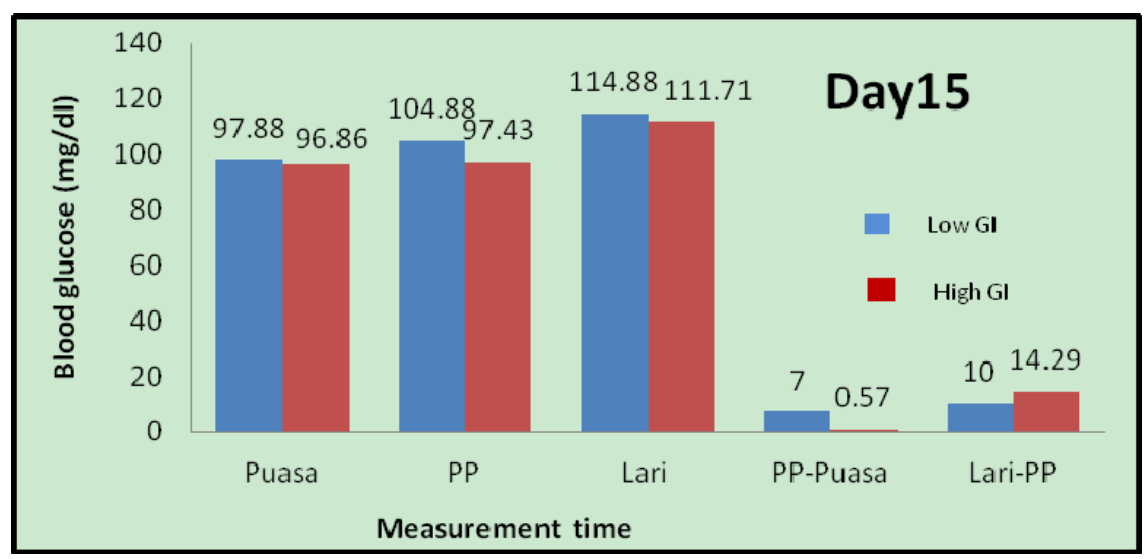

Figure 2. The average blood glucose levels of subjects on day 15

The consumption of high-GI meal is seemingly able to increase the reserve of hepatic and muscle glycogens that is higher than low-GI meal. During training, this glycogen reserve will be broken down by the body as a source of energy. This is in line with the investigation results from Wee et al. (2005), which suggests that a high-GI meal consumed before doing sport training/practices provide a greater contribution to muscle glycogen reserve than that of low-GI meal. This suggestion is confirmed by the finding of Burke et al. (1993), explaining that the increase of muscle glycogen after 24 hours in recovery from sport practices that exhaust oxygen is higher after consuming high-GI meal than low-GI meal.

In the subjects consuming low-GI meal, the glucose will be released more gradually than those with high-GI meal. The number of blood glucose will be relatively stable in the subjects consuming low-GI meal rather than those consuming high-GI meals. In high-GI meal, the blood glucose level will rise drastically and slow down quickly to basal condition. The low-GI meal is digested slowly so that the storage process is also decreasing. This will be a benefit for an athlete since the glucose will be available until the last sport activities. The high content of muscle glycogens at the time before practices will increase the carbohydrate oxidation (Arkinstall et al., 2004).

The research of Thomas et al. (1994) suggests that the plasma glucose level after training relates to GI in the food provided before training. In consuming a high-GI meal before practicing sport, the concentration of blood glucose will rise and lower sharply and attain a higher level at peak times than in consuming low-GI meal with similar number of carbohydrates (Mondazzi et al., 2009). This finding is confirmed by Burke et al. (1998) and Cocate et al. (2011) suggesting that the rate of glucose oxidation is higher after consuming high-GI meal.

The decrease of blood glucose level occurs after 5-km run within high-IG group; this is presumably caused by the insulin level after meal consumption (before training) is still high enough in high-GI group, bringing the glucoses into liver and muscle to be stored as glycogens and reducing the glucose production in liver (Marmy-Cornus et al., 1996). As Coyle (1991) said, the influence of insulin on peripheral tissue is seemingly longer although the insulin level has reduced to the fasting level. This influence of stable increasing insulin level is likely to enable blood glucose uptake by muscles remaining to be elevated in high-GI group rather than in low-GI group (Wee et al., 1999).

Insulin is an important hormone, which regulates the use of energy by body tissues. Insulin provides anabolic effects in body metabolism such as the forming of glycogens, triacylglycerol and proteins. On day 1 during the intervention, the average level of blood insulin within the subjects in low-GI group is $7.98 \pm 4.85 \mu \mathrm{IU} / \mathrm{mL}$, while for those in high-GI group it is $10.21 \pm 8.11 \mu \mathrm{IU} / \mathrm{mL}$. After meal consumption, the average level of serum insulin in the high-GI group is higher than in the low-GI group; it happens also with the average level of serum insulin after $5-\mathrm{km}$ run on treadmill. After running, the insulin level of both treatment groups experience a reduction, and the highest average difference of insulin reduction occur in the high-GI group. The results of statistical tests suggest that on day 1 , there is a significant difference in the average level of serum insulin after meal consumption in the two treatments $(p<0.05)$. The average levels of serum insulin in the first-day measurement in both treatment groups is shown in Figure 3. 


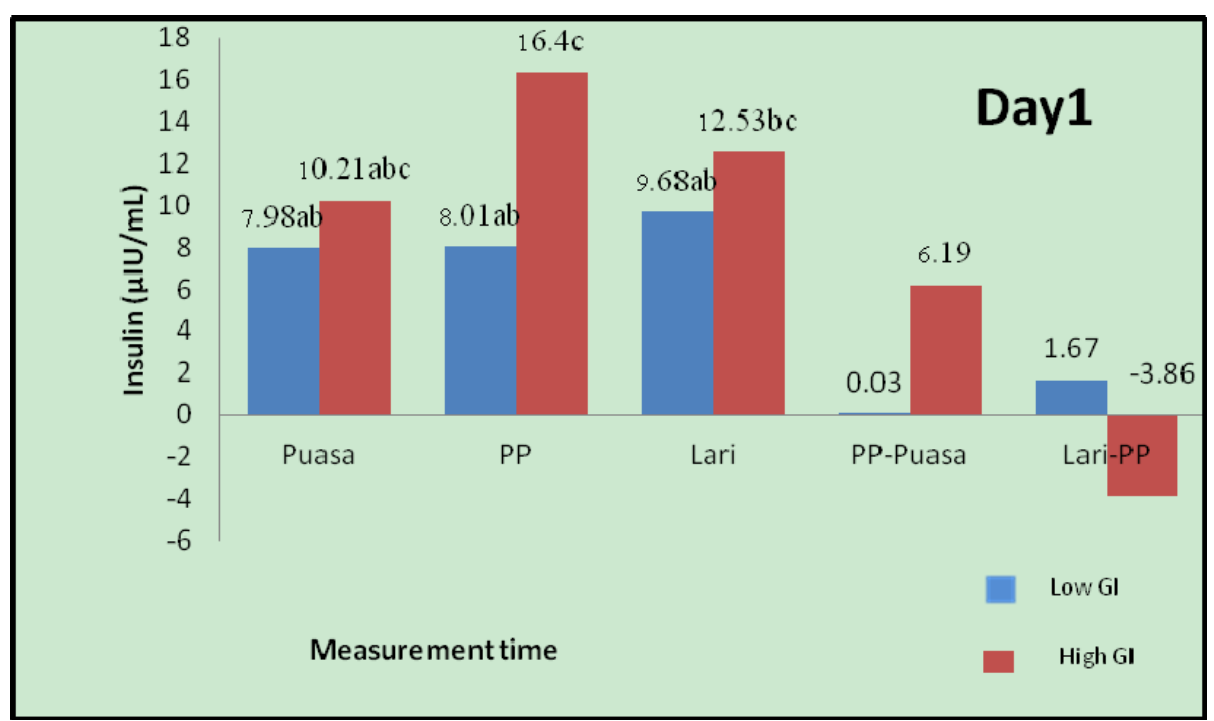

Figure 3. The average levels of serum insulin on day 1

This finding is similar with the research of Stevenson et al. (2005) in which he has consumed the mixtures of high GI and low GI meals at breakfast and lunch before running on treadmill and found that postprandial insulin concentrations after 1 hour and 2 hours are significantly higher in the high GI than in the low GI. In the initial training, the value of insulin concentration is similar to the fasting value in low GI, but in high GI it remains $150 \%$ higher than the value of insulin concentration when fasting. This is also suggested by research conducted by Wong et al. (2008) in which he provided the mixtures of high GI and low GI meals containing $65 \%$ carbohydrates, $15 \%$ proteins, and $20 \%$ fats of the total calories. He found that the concentration of serum insulin during postprandial period is higher in high-GI meal than in low-GI meal. The finding of Stevenson (2006) in the female subjects who were given high- and low-GI breakfasts also suggests that the concentration of serum insulin is significantly higher in high-GI treatment than low-GI treatment, and the concentration of insulin is reduced following the postprandial period of both treatments but remains higher in high-GI than low-GI treatment $(\mathrm{p}<0.05)$.

On the $15^{\text {th }}$ day of intervention, the average level of serum insulin two hours after meal (postprandial) and after $5-\mathrm{km}$ run within high-GI group is relatively higher than low-GI group. The pattern of increasing serum insulin level in high-GI group is in line with the increasing blood glucose level in high-GI group both in PP and after $5-\mathrm{km}$ run. The average level of serum insulin on the $15^{\text {th }}$ day measurement within the two treatment groups is shown in Figure 4.

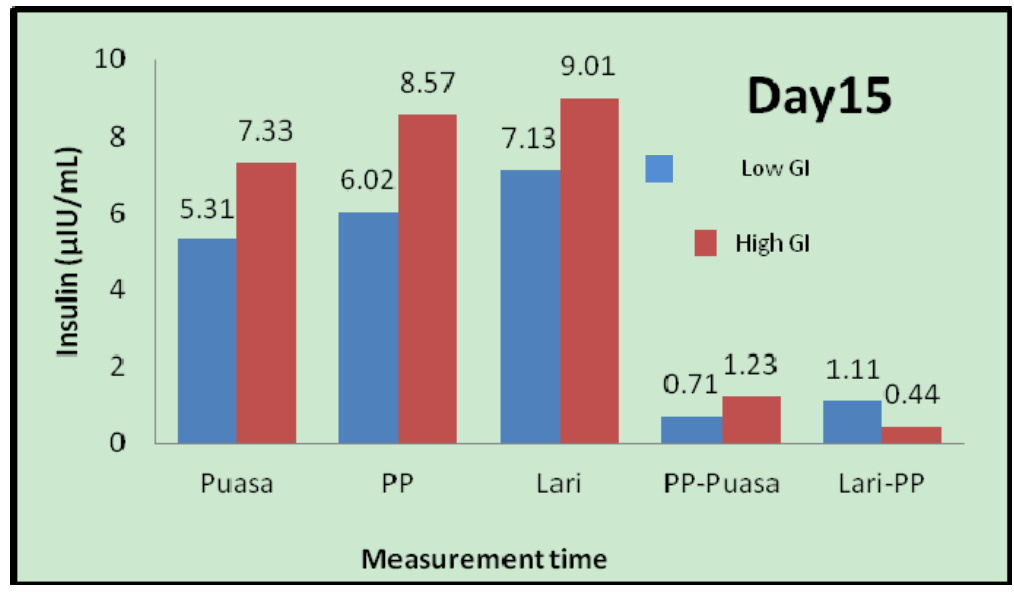

Figure 4. The average levels of serum insulin on day 15

On the $15^{\text {th }}$ day, seemingly the subject bodies underwent an adaption condition so that the difference of insulin 
levels two hours after meal consumption is not seen; however, a tendency of serum insulin level within high-GI group is still larger than low-GI group. The increase in insulin level after meal consumption and after 5-km run on the day 15 is caused by the increases in glucose level in high-GI group. Apparently digestion and absorption processes of food still exist, therefore the glucose is still increasing (Wee et al., 1999). The main factors that contribute to regulating the blood glucose levels are the blood glucose concentration itself and the hormones particularly insulin and glucagon (Marks et al., 2000).

Endurance can be connoted with a body ability to resolve fatigue or body capacity to receive burdens as long as possible both in static and dynamic situations without reducing work quality. In this research the endurance performance is defined as the ability of subject to complete $5-\mathrm{km}$ run within a certain time. On the first day of intervention, the research findings show that the average finishing time for $5-\mathrm{km}$ run in low-GI group is $23.8 \pm$ 1.6 minutes lower than in high-GI group $(27.5 \pm 2.2$ minutes $)$. On the $15^{\text {th }}$ day of intervention, the finishing time of $5-\mathrm{km}$ run in low-GI group remains lower $(23.9 \pm 1.5$ minutes) than in high-GI group ( $26.9 \pm 3.1$ minutes). There is a significant difference in the finishing time of $5-\mathrm{km}$ run between the two treatment groups $(\mathrm{p}<0.05)$. The average performance of $5-\mathrm{km}$ run endurance can be seen in Table 2 .

Table 2. The endurance performance in 5-km run

\begin{tabular}{ccccc}
\hline Variable & Time & Low IG $(\mathrm{n}=6)$ & High IG $(\mathrm{n}=6)$ & $\mathrm{p}$ value \\
\hline Time (minutes ) & Day 1 & $23.8+1.6$ & $27.5+2.2$ & 0.008 \\
& Day 15 & $23.9+1.5$ & $26.9+3.1$ & 0.05 \\
& p value & 0.915 & 0.573 & \\
\hline
\end{tabular}

There is an effect of meal consumption with different GI on the time necessary for subjects to finish the 5-km run. The performance or the finishing time in 5-km run in low-GI group is better than that of high-GI group both before and after interventions. The shorter time taken for finishing the $5-\mathrm{km}$ run in high-GI group when compared with high-GI subjects is presumably because the subjects consuming low-GI meal have relatively more stable glucose availability as an energy source than those consuming high-GI meal. The result of this research is in line with the research conducted by Wong et al. (2008) which suggests that the subjects with low-GI meal show faster finishing times when compared with those with high-GI meal (low GI $=98.7$ minutes and high GI $=101.5$ minutes). The same result of investigation is also obtained from $\mathrm{Wu}$ and Williams (2006), which suggest that the endurance capacity of subjects taking low-GI meal three hours before running on treadmill is larger than those with high-GI meal. Moore et al. (2009) also concludes that the performance of cyclists significantly increased in low-GI treatment (92.5 \pm 5.2 minutes) rather than high-GI treatment (95.6 \pm 6.0 minutes).

The faster time in reaching the finish line in low-GI intervention can be explained by the probable large number of carbohydrates that have not been oxidized still remains in the small intestine on initial sport activities and are subsequently released into blood gradually (Burke et al., 1998; Thorne et al., 1983). The meal with high GI experienced faster digestion and absorption, and glucose transport into the circulation system, causing the larger blood glucose frequency than low-GI meal. In high-GI meal, the blood glucose will be stored optimally as muscle glycogens that are reduced as they are used in doing sports. This is similar to the finding of Wong et al. (2008), which suggests that the blood glucose concentration remains high during sport activity after consuming low-GI meal. Moore et al. (2000) in his research also describes that the blood glucose level at fatigue point after bicycling is higher in low-GI treatment $(5.2 \pm 0.6 \mathrm{mmol} / \mathrm{L})$ than high-GI treatment $(4.7 \pm 0.7 \mathrm{mmol} / \mathrm{L})$. According to Marmy-Conus et al. (1996), this response could happen because, after consuming high-GI meal, the serum insulin concentration during postprandial is higher that it plays a role in reducing the hepatic glucose production and increasing the glucose transport into muscles. The influence of insulin concentration on peripheral tissue sustains for longer time, although the concentration will return to the fasting value (Coyle, 1991; Montain et al., 1991). The influence of sustainable hyperinsulinemia causes the increase of glucose uptake during the high-GI consumption become larger than that of during the low-GI consumption (Wee et al., 1999).

In high-GI treatment, the availability of hepatic glycogen reserve has been adequate, and possibly the sport practice causes the increasing hepatic glucose output that is simultaneous to the increasing glucose uptake by muscles during the sport training. When the sport practice continues, the hepatic glycogen storage will be inadequate to meet the increasing glucose uptake by muscle, causing the drastic reduced glucose concentration until the last training. This can explain why the blood glucose concentration is more stable in low IG treatment 
and decreases to the fasting value in the last training in high-GI treatment (Wong et al., 2008). The reduction of carbohydrate reserve is one of the primary causes for an exacerbation of performance and an increase of fatigue during the long-term sport in sub-maximal running (Wong \& Williams, 2000). According to Costill, the muscle glycogens depend on training intensity, physical condition, training type, environmental temperature, and meal before training (Costill, 1988). The reduction of carbohydrates causes the inability of muscles to produce ATP again as the rate of ATP decreases. The inadequacy of carbohydrates leads to the reducing pyruvate in muscles as substrates in forming acetyl CoA and in trycarboxylate acid reaction.

\section{Conclusion and Suggestion}

The endurance performance of 5-km run is better in low-GI group than in high-GI group; this is because there is an influence of meal consumption with different GIs on the college athletes $(p<0.05)$. On the first day of intervention, there is a significant difference in the average level of postprandial insulin between the two treatments $(\mathrm{p}<0.05)$; however, on the $15^{\text {th }}$ day of intervention there is no difference in the average level of insulin between the two treatments but there is a higher tendency of average insulin level in high-GI than low-GI treatments. There is no significant difference in the average blood glucose level between treatments, but there is a higher tendency of blood glucose level after $5-\mathrm{km}$ running in low-GI treatment both on the first and $15^{\text {th }}$ days of interventions.

Based on the results of the research it can be concluded that the consumption of low-GI meal before sport activity can better improve the performance in $5-\mathrm{km}$ run. The relevant stakeholders should hold an awareness campaigns or programs about proper meal intake to reach an optimal performance for athletes, especially related to glycemic index of the meals.

\section{References}

[Depdiknas] Departemen Pendidikan Nasional. (2000). Pedoman dan Modul Pelatihan Kesehatan Olahraga Bagi Pelatih Olahragawan Pelajar. Jakarta: Pusat Pengembangan Kualitas Jasmani.

Burke, L. M., Collier, G. R., \& Hargreaves, M. (1993). Muscle glycogen storage after prolonged exercise:effect of the glycemic index of carbohydrate feedings. J App Physiol, 75(2), 1019-1023.

Burke, L. M., Collier, G. R., \& Hargreaves, M. (1998). Glycemic index-a new tool in sport nutrition? International Journal of Sport Nutrition, 8, 401-415.

Chen et al. (2008). Effect of preexercise meals with different glycemic indices and loads on metabolic responses and endurance running. Int J Sport Nutr. Exerc. Metab, 18, 281-300.

Cocate et al. (2011). Metabolic responses to high glycemic index and low glycemic index meals: a controlled crossover clinical trial. Nutrition Journal, 10(1). http://dx.doi.org/10.1186/1475-2891-10-1

Costill, D. L. (1988). Carbohydrate for exercise: dietary demands for optimal performance. Int J Sports Med, 9 , 1-18. http://dx.doi.org/10.1055/s-2007-1024971

Coyle, E. F., Hamilton, M. T., Alonso, J. G., Montain, S. J., \& Ivy, J. L. (1991). Carbohydrate metabolism during intense exercise when hyperglycemic. Journal of Applied Physiology, 70(2), 834-840.

Jenkins et al. (1981). Glycemic index of foods: A physiological basis for carbohydrate exchange. Am J Clin Nutr, 34, 362-366.

Jeukendrup, A., \& Gleeson, M. (2004). Sport Nutrition An Introduction to Energy Production and Performance. New Zealand:Human Kinetic.

Marks, D. B., Marks, A. D., \& Smith, C. M. (2000). Biokimia Kedokteran Dasar: Sebuah Pendekatan Klinis. Jakarta:Penerbit Buku Kedokteran.

Marmy-Conus, N., Fabris, S., Proietto, J., \& Hargreaves, M. (1996). Preexercise glucose ingestion and glucose kinetics during exercise. J Appl Physiol, 81(2), 853-857.

Mitchell et al. (1997). The effect of preexercise carbohydrate status on resistence Exercise performance. Int $J$ Sport Nutr Exerc Metab, 17, 185-196.

Mondazzi, L., \& Arcelli, E. (2009). Glycemic Index in Sport Nutrition. Journal of the American College of Nutrition, 28, 455S-463S. http://dx.doi.org/10.1080/07315724.2009.10718112

Montain, S. J., Hopper, M. K., Coggan, A. R., \& Coyle, E. F. (1991). Exercise metabolism at different time intervals after a meal. Journal of Applied Physiology, 70(2), 882-888.

Moore, L. J. S., Midgley, A. W., Thomas, G., Thurlow, S., \& McNaughton, L. R. (2009). The effect of low and 
high glycemic index meals on time trial performance. International Journal of Sports Physiology and Performance, 4, 331-344.

Mougios, V. (2006). Exercise Biochemistry. USA:Human Kinetic.

Powers, S. K., \& Howley, E. T. (1997). Theory and application to fitness and performance. In J. A. Barnes, \& S. G. DeVries (Eds.), The Effects of water or sport drink ingestion prio to exercise on the performance of middle distance, amateur runners in thermoneutral environment [Tesis]. Michigan:Grand Valley Satet University.

Rimbawan, \& Siagian, A. (2004). Indeks Glikemik Pangan. Cara Mudah Memilih Pangan yang Menyehatkan. Jakarta:Penebar Swadaya.

Stannard, S. R., Thompson, M. W., \& Miller, J. C. B. (2000). The effect of glycemic index on plasma glucose and lactate level during incremental exercise. Int. J. Sport Nutr. Exerc. Metab, 10, 51-61.

Stevenson, E. J., Williams, C., Mash, L. E., Philips, B., \& Nute, M. L. (2006). Influence of high carbohydrate mixed meals with different glycemic indexes on substrate utilization during subsequent exercise in women. Am J Clin Nutr, 84, 354-360.

Stevenson, E., Williams, C., \& Nute, M. (2005). The influence of the glycaemic index of breakfast and lunch on substrate utilisation during the postprandial periods and subsequent exercise. $\mathrm{Br} J$ Nutr, 93, 885-893. http://dx.doi.org/10.1079/BJN20051430

Sukmaniah, S., \& Prastowo, S. M. B. P. (1992). Gizi Untuk Olahragawan. Jakarta:Direktorat Bina Gizi Masyarakat, Depkes RI.

Thomas, D. E., Brotherhood, J., \& Brand Miller, J. C. (1994). Carbohydrate feeding before exercise and glycemic index. Am J. Clin. Nutr, 59(Suppl), 791S.

Thorne, M. J., Thompson, L. U., \& Jenkins, D. J. A. (1983). Factors affecting starch digestibility and the glycemic response with special reference to legumes. Am J Clin Nutr, 38, 481-488.

Wee, S. L., Williams, C., Gray, S., \& Horabin, J. (1999). Influence of high and low glycemic index meals on endurance running capacity. Med Sci Sports Exerc., 31, 393-399. http://dx.doi.org/10.1097/00005768-199903000-00007

Wee, S. L., Williams, C., Tsintzas, K., \& Boobis, L. (2005). Ingestion of a high-glycemic index meal increases muscle glycogen storage at rest but augments its utilization during subsequent exercise. $J$ Appl Physiol, 99, 707-714. http://dx.doi.org/10.1152/japplphysiol.01261.2004

Wong et al. (2008). Effect of the glycaemic index of pre-exercise carbohydrate meals on running performance. European Journal of Sport Science, 8, 23-33. http://dx.doi.org/10.1080/17461390701819451

Wong, S. H., \& Williams, C. (2000). Influence of different amounts of carbohydrate on endurance running capacity following short term recovery. International Journal of Sports Medicine, 21, 444-452. http://dx.doi.org/10.1055/s-2000-3831

Wu, C. L., \& Williams, C. (2006). A low glycemic index meal before exercise improves endurance running capacity in men. Int. J. Sport Nutr. Exerc. Metab, 16, 510-527.

\section{Copyrights}

Copyright for this article is retained by the author(s), with first publication rights granted to the journal.

This is an open-access article distributed under the terms and conditions of the Creative Commons Attribution license (http://creativecommons.org/licenses/by/3.0/). 